\title{
Effect of Slow Cooling in Reducing Pore Size in a Sintered Powder Metallurgical 6061 Aluminium Alloy
}

\author{
S. Solay Anand ${ }^{1 *}$, B. Mohan ${ }^{2}$, T. R. Parthasarathy ${ }^{3}$ \\ ${ }^{1}$ Department of Mechanical Engineering, Adhiparasakthi Engineering College, Melmaruvathur, Tamil Nadu, India; ${ }^{2}$ Department of \\ Production Technology, MIT Campus, Anna University, Chennai, India; ${ }^{3}$ Metallurgist, MetMech Engineers, Chennai, India. \\ Email: ssrajsolayanand@yahoo.in,mohan@mitindia.edu, metmech2005@yahoo.co.in
}

Received December $15^{\text {th }}, 2010$; revised January $24^{\text {th }}, 2011$; accepted May 25 $5^{\text {th }}, 2011$.

\begin{abstract}
The usage of powder metallurgy aluminium compacts in lieu of ferrous components in automotives helps to lower vehicle weight. The major drawback in the commercially available press sintered aluminium alloy is porosity which is mainly dependent on the powder metallurgical process parameters such as compaction pressure, sintering temperature and cooling rate after sintering. In this paper the effect of particle size and furnace controlled cooling after sintering on porosity level and micro hardness of an elemental 6061 aluminium alloy has been investigated. Aluminium particle sizes of $20 \mu \mathrm{m}$ and $150 \mu \mathrm{m}$ were used. The elemental 6061 aluminium alloy powders are warm compacted at $175 \mathrm{MPa}$. After sintering for about one hour at $600^{\circ} \mathrm{C}$, the aluminium compacts were furnace cooled at the rate of $1^{\circ} \mathrm{C} / \mathrm{min}$ to different temperatures of $500^{\circ} \mathrm{C}, 400^{\circ} \mathrm{C}, 300^{\circ} \mathrm{C}$ and $200^{\circ} \mathrm{C}$. When the cooling temperature after sintering inside the furnace is effected at various temperatures from $600^{\circ} \mathrm{C}$ to $200^{\circ} \mathrm{C}$, for a precipitate hardened aluminium compacts with aluminium particle size of $20 \mu \mathrm{m}$, the porosity level reduced by $26 \%$ and that for aluminium particle size of $150 \mu \mathrm{m}$, the porosity level reduced by 23\%. Marked improvement in micro hardness value is also observed correspondingly.
\end{abstract}

Keywords: Powder Metallurgy, Particle Size, Cooling Rate, Precipitation Hardening, Porosity

\section{Introduction}

Due to revolution in automobile industry towards light weight metals, there is a particular interest in aluminium matrix composites [1,2], especially through powder metallurgy $(\mathrm{P} / \mathrm{M})$, as it is a means by which complex, net shape light weight components can be produced cost effectively [3]. The main drawback in $\mathrm{P} / \mathrm{M}$ components is porosity. Sintered materials are typically characterized by residual porosity after sintering, which is quite detrimental to the mechanical properties of these materials [4, 5]. The nature of porosity can be controlled by several processing variables such as compaction pressure, sintering temperature and time, alloying additions and particle size of initial powders [4]. In particular, the fraction, size, distribution and morphology of the porosity have a profound impact on mechanical behavior of P/M components [5-8]. Porosity in sintered alloys are mainly due to 1) primary pores carried over from green state and arising from the removal of the lubricant wax which are not entirely eliminated by shrinkage phenomena; 2) secondary pores generated by the diffusion of alloying elements into the major phase, leaving residual porosity located at the sites of the original alloy particles; 3 ) bubbles generated by the vaporization of a volatile phase [9]. In the early works $[10,11]$ on various aluminium alloy powder compacts it is clearly shown that the progression of sintering and the final porosity in the system is also dependant on the process variables such as additive particle size, heating rate and the final sintering temperature.

Current commercial aluminium powder metallurgy alloys are based on the wrought 6xxx series (Al-Mg-Si) and 2xxx series (Al-Cu-Mg) of alloys, where as little research has been conducted using elemental powders. This work was therefore undertaken to ascertain whether the data on porosity level of artificial hardened elemental 6061aluminium P/M alloy has any adverse effect on furnace controlled cooling from sintering temperature after sintering. During furnace controlled cooling from sintering temperature, the levels of porosity along with density 
and micro hardness were also examined for two different particle size of aluminium powders.

\section{Experimental Methods}

The composition of the elemental 6061Al alloy considered for this experimental study is shown in Table 1. Two different particle sizes of aluminium powders of $20 \mu \mathrm{m}$ and $150 \mu \mathrm{m}$ are selected for this study. Aluminium powders of irregular shapes are produced by atomization process as received from Metal Powder Company. SEM images of aluminium powders used are shown in Figure 1.

Utmost care has been taken in order to maintain uniformity in alloy composition for all compacts. The schematic of the powder metallurgical process is shown in Figure 2. For 500 grams of aluminium powder, each alloy powder of the 6061 alloy composition is weighed to an accuracy of three decimals of a gram, with the help of microbalance. Each alloying element was mixed with aluminium powder in an electric mixer running at $50 \mathrm{rpm}$ for 10min. According to density calculations for 6061 aluminium alloy used, 96.15grams of blend is taken for each compact of size $70 \times 50 \times 10 \mathrm{~mm}^{3}$. The blend prepared is poured out in a rectangular die of size $70 \times 50 \times$ $30 \mathrm{~mm}^{3}$ and warm compacted at $175 \mathrm{MPa}$ in a uniaxial hydraulic press of 100 Tonnes capacity. The die and plunger temperature is maintained at $150^{\circ} \mathrm{C}$ and $170^{\circ} \mathrm{C}$ respectively. Paraffin wax is used as die wall lubricant for each compact. The green compacts obtained are dewaxed at $300^{\circ} \mathrm{C}$ for about $20 \mathrm{~min}$. and sintered at $600^{\circ} \mathrm{C}$ in a high purity nitrogen atmosphere (dew point $<-60^{\circ} \mathrm{C}$ ) for one hour. Nitrogen gas is passed at the rate of 3 lit/min. After sintering, the sintered compacts are cooled inside the furnace at a rate of $1^{\circ} \mathrm{C} / \mathrm{min}$ and taken out at various temperatures of $600^{\circ} \mathrm{C}, 500^{\circ} \mathrm{C}, 400^{\circ} \mathrm{C}, 300^{\circ} \mathrm{C}$, $200^{\circ} \mathrm{C}$ and air cooled. The sintered compacts were solution heat treated (SHT) at $530^{\circ} \mathrm{C}$ for $90 \mathrm{~min}$, water quenched and precipitate hardened (artificial aging) at $170^{\circ} \mathrm{C}$ for 6 hrs.

Aluminium compacts were tested for Vickers micro hardness by using Wilson's micro hardness tester at 0.5 kgf load. Percentage of volume porosity is found out at various regions according to ASTM B276 standards by using dewinter Material plus software coupled online with optical microscope of $1000 \mathrm{X}$ magnification. Density measurements were done according to ASTM standard B328.

\section{Results and Discussion}

The effects of furnace cooling temperature after sintering of 6061 aluminium compacts with aluminium particle size of $20 \mu \mathrm{m}$ and $150 \mu \mathrm{m}$ on porosity, density and micro hardness have been discussed below.

\subsection{Porosity}

Figures $\mathbf{3}$ and $\mathbf{4}$ show microstructure of a precipitate hardened 6061 aluminium compact with aluminium particle size of $20 \mu \mathrm{m}$ and $150 \mu \mathrm{m}$, for a furnace cooled temperature of $600^{\circ} \mathrm{C}, 500^{\circ} \mathrm{C}, 400^{\circ} \mathrm{C}, 300^{\circ} \mathrm{C}$ and $200^{\circ} \mathrm{C}$ after sintering. From these microstructures it is observed that the pore size get reduced as furnace cooled temperature after sintering reduces from $600^{\circ} \mathrm{C}$ to $200^{\circ} \mathrm{C}$ irrespective of the aluminium particle size used. It is also observed that the size of the phases formed during sintering alsogets reduced, as the furnace controlled cooling

Table 1. Composition of 6061 Aluminium alloy used in the present work.

\begin{tabular}{cccccccccc}
\hline Material & $\mathrm{Mg}$ & $\mathrm{Si}$ & $\mathrm{Cu}$ & $\mathrm{Fe}$ & $\mathrm{Zn}$ & $\mathrm{Sn}$ & $\mathrm{Mn}$ & $\mathrm{Al}$ \\
\hline Composition in wt.\% & 1.2 & 0.6 & 0.3 & 0.7 & 0.25 & 0.3 & 0.3 & 96.75 \\
\hline
\end{tabular}

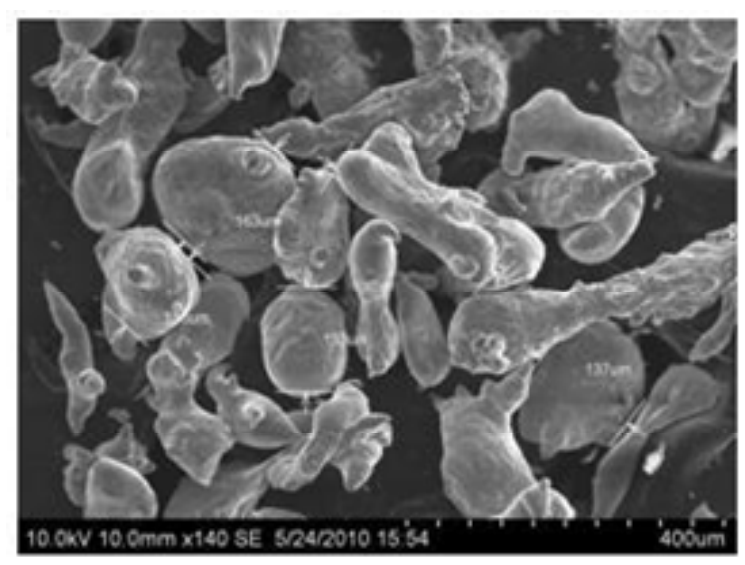

(a)

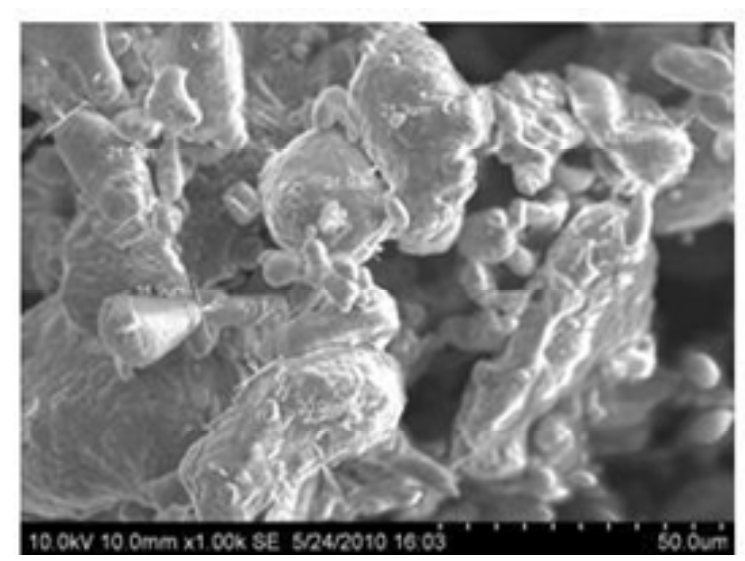

(b)

Figure 1. SEM images of aluminium powders of particle size (a) $20 \mu \mathrm{m}$ and (b) $150 \mu \mathrm{m}$. 


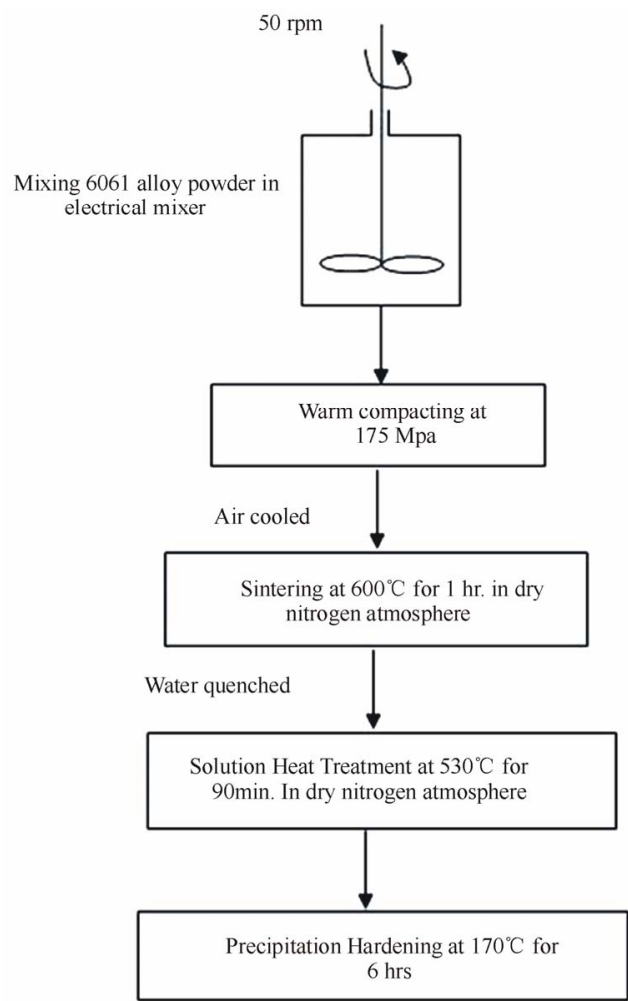

Figure 2. Schematics of Specimen preparation.

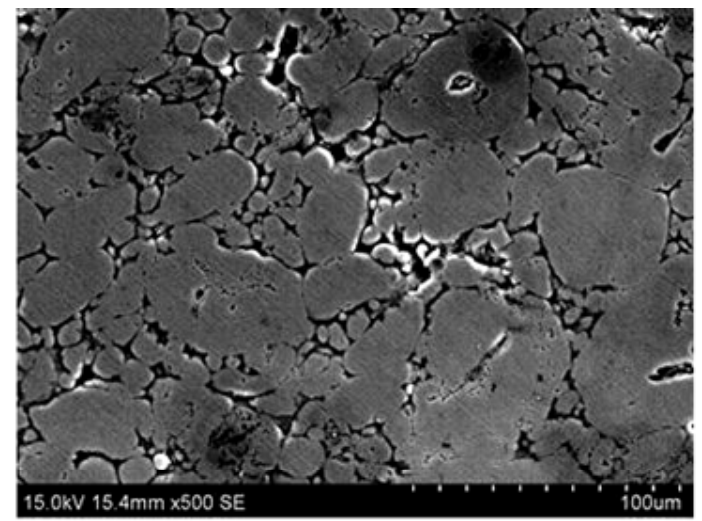

(a)

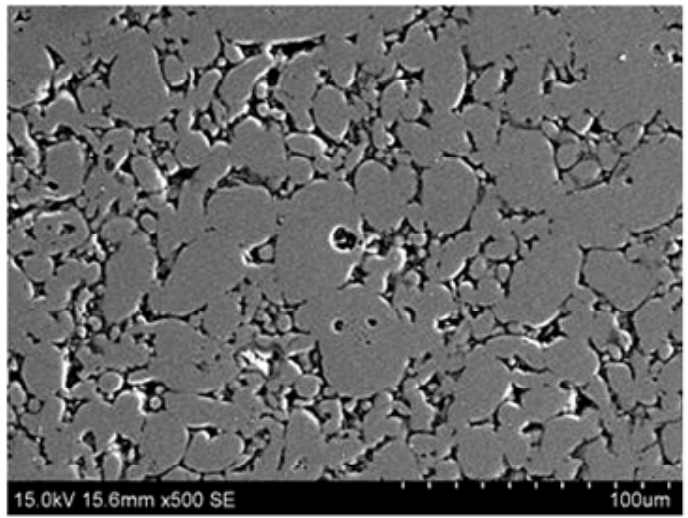

(b)

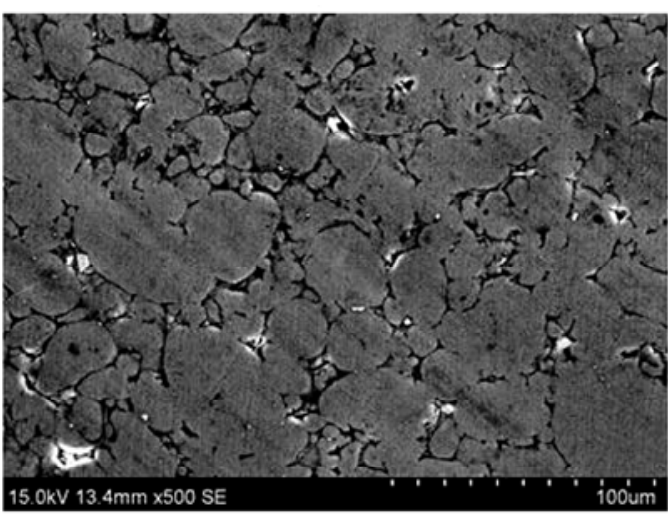

(c)

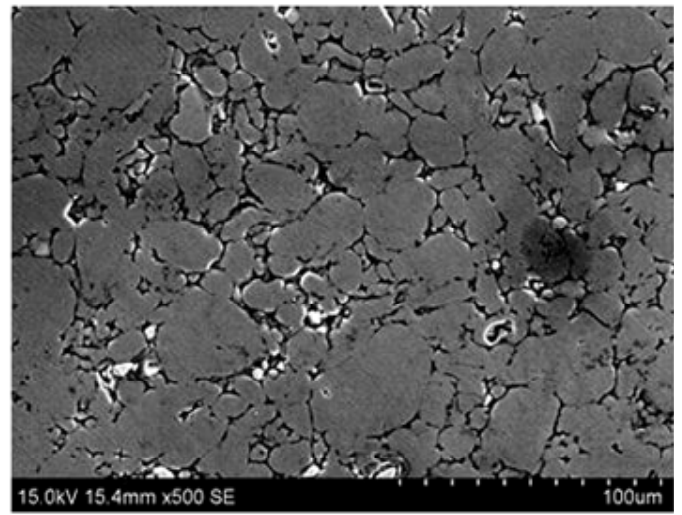

(d)

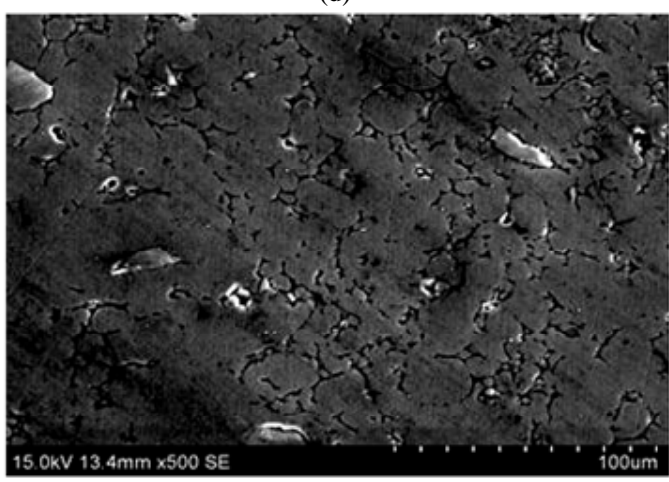

(e)

Figure 3. SEM images of 6061 precipitate hardened aluminium compact with aluminium particle size of $20 \mu \mathrm{m}$, at a fumace cooled temperature of (a) $600^{\circ} \mathrm{C}$, (b) $500^{\circ} \mathrm{C}$, (c) $400^{\circ} \mathrm{C}$, (d) $300^{\circ} \mathrm{C}$ and (e) $200^{\circ} \mathrm{C}$.

after sintering is effected from $600^{\circ} \mathrm{C}$ to $200^{\circ} \mathrm{C}$ which is mainly due to the precipitation of these phases in to the aluminium matrix.

Furthermore these phases get dispersed into the aluminium matrix during solution heat treatment followed by precipitation hardening. Figure 5 shows the EDAX at aluminium matrix of sintered 6061 aluminium compact, from which it is observed that the phases formed are composed of silicon, magnesium copper and traces of tin- 


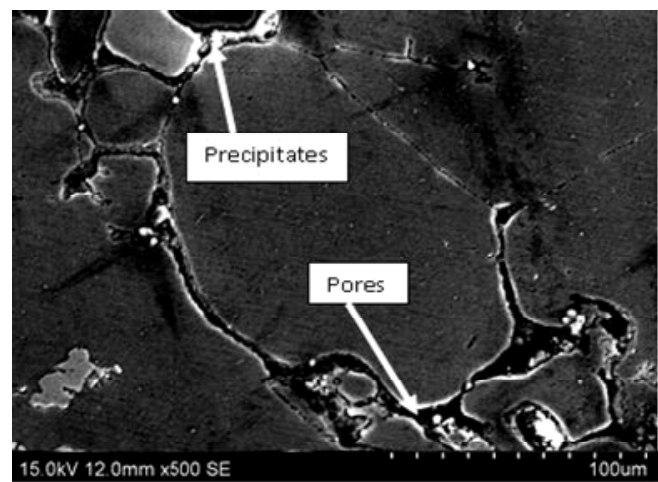

(a)

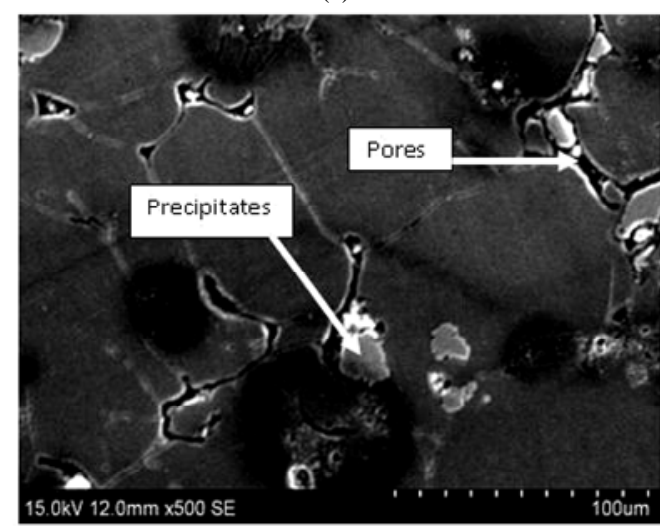

(b)

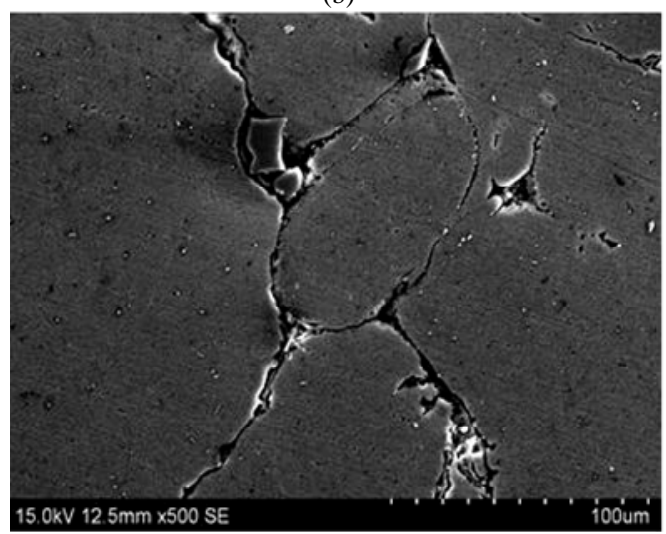

(c)

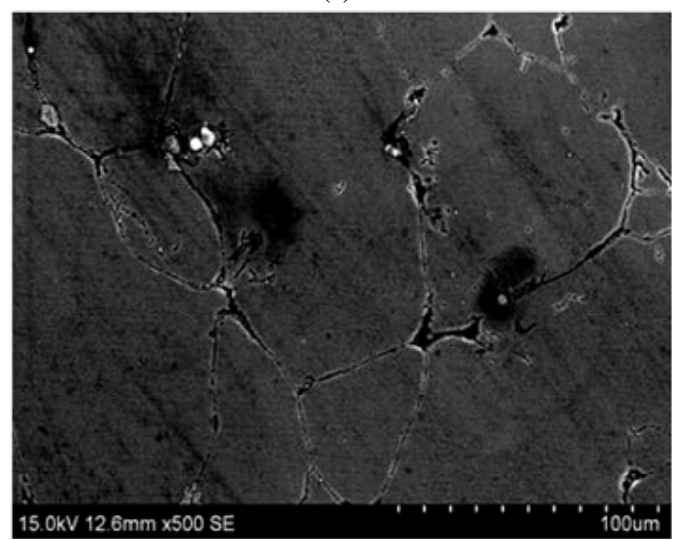

(d)

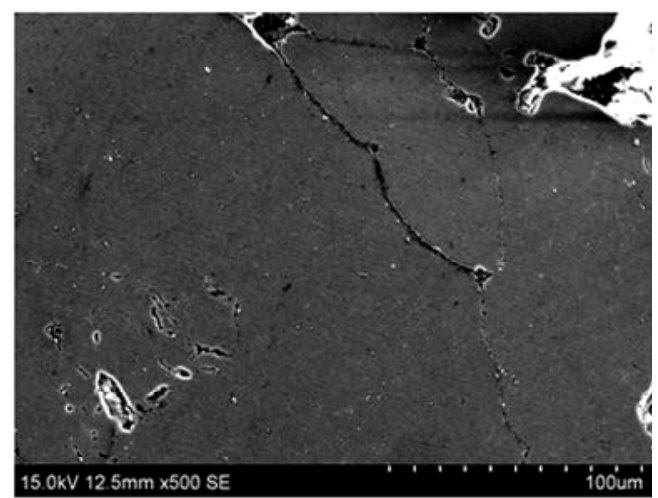

(e)

Figure 4. SEM image of 6061 precipitate aluminium compact with aluminium particle size of $150 \mu \mathrm{m}$, at a fumace cooled temperature of (a) $600^{\circ} \mathrm{C}$, (b) $500^{\circ} \mathrm{C}$,(c) $400^{\circ} \mathrm{C}$,(d) $300^{\circ} \mathrm{C}$ and (e) $200^{\circ} \mathrm{C}$.

and zinc. Form this it is speculated that the phases mainly formed are $\mathrm{Mg}_{2} \mathrm{Si}, \mathrm{Al}-\mathrm{Si}, \mathrm{Al}_{2} \mathrm{Cu}$ and $\mathrm{Mg}_{2} \mathrm{Zn}$ [12].

Figure 6 and Figure 7 shows the optical microstructure of precipitation hardened 6061 aluminium compact with an aluminium particle size of $20 \mu \mathrm{m}$ and $150 \mu \mathrm{m}$, furnace cooled after sintering at $600^{\circ} \mathrm{C}$ and $200^{\circ} \mathrm{C}$. The phases of $\mathrm{Mg}_{2} \mathrm{Si}$ particles (which are dark and tiny) which are dispersed inside the grain boundaries are visible in the microstructure shown in Figure 6. The finer particles of $\mathrm{Mg}_{2} \mathrm{Si}$ (dispersed inside the aluminum grains as visible in Figure 7) are due to precipitation after solutionising.

Very low AlSi eutectics could be seen as the silicon has combined with Magnesium to form $\mathrm{Mg}_{2} \mathrm{Si}$. In comparison with cooling from $600^{\circ} \mathrm{C}$ after sintering, more effective fusion of the grains were observed at different fields, as the cooling is effected from $200^{\circ} \mathrm{C}$ after sintering. Due to the precipitation of these phases during the slow furnace controlled cooling at $200^{\circ} \mathrm{C}$ the grain size of the aluminium particle increased.

Figure 8 show the gain size measurement of precipitate hardened 6061 aluminium compact with aluminium particle size of $150 \mu \mathrm{m}$, at a furnace cooled temperature of $600^{\circ} \mathrm{C}$ and $200^{\circ} \mathrm{C}$ after sintering, by using dewinter software. The grain size of the aluminium matrix measured optically(curved line length along grain boundary Figure 8), seem to be changed as the cooling is effected upto $200^{\circ} \mathrm{C}$. Higher grain size for a furnace cooled temperature of $200^{\circ} \mathrm{C}$ indicates continous grain growth which in turn leading to decrease in pore size. The porosity level as measured according to ASTM B276 by the dewinter material plus software for aluminium compacts furnace cooled at various temperature with aluminium particle size of $20 \mu \mathrm{m}$ and $150 \mu \mathrm{m}$, after sintering, solution heat treatment and precipitate hardened 


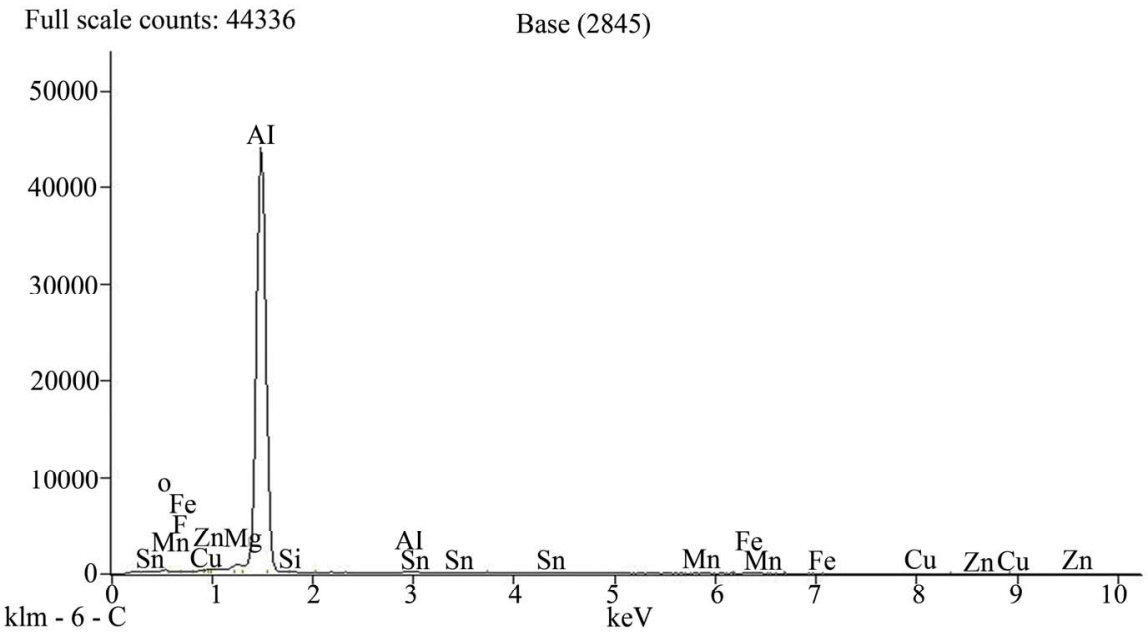

Figure 5. EDAX of the sintered 6061 aluminium compact showing the various compositions present in the phases formed.

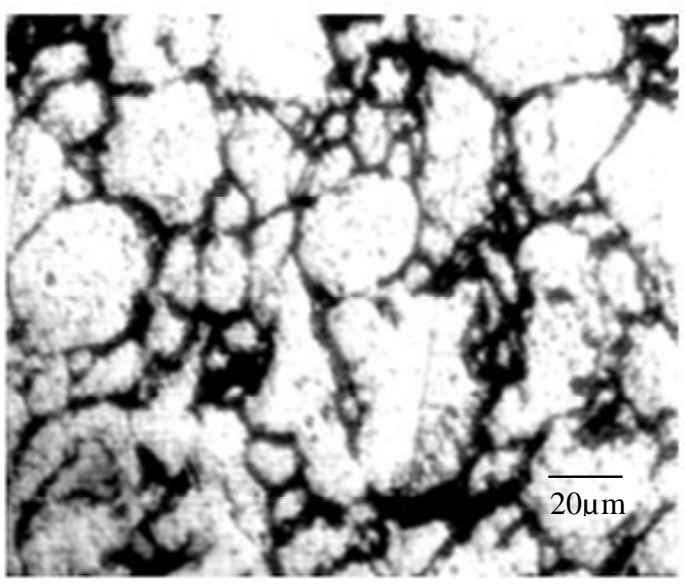

(a)

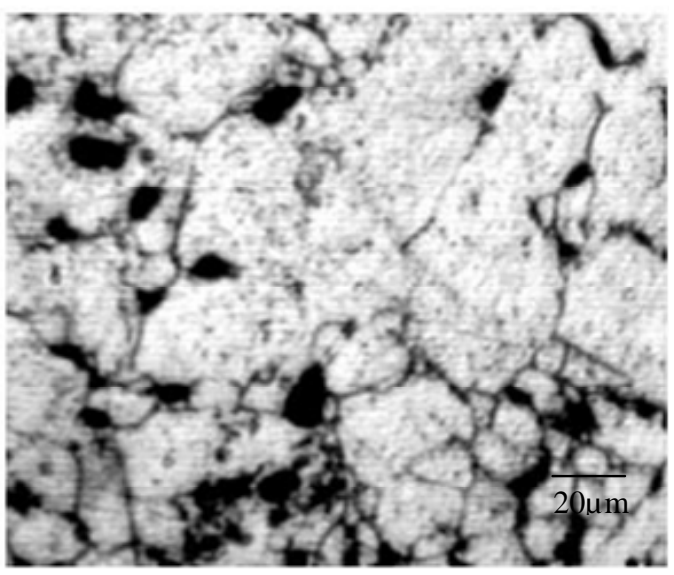

(b)

Figure 6. Optical microstructure of precipitation hardened 6061 aluminium compact with aluminium grain size of $20 \mu \mathrm{m}$ at a furnace cooled temperature of (a) $600^{\circ} \mathrm{C}$ and (b) $200^{\circ} \mathrm{C}$ after sintering, at a magnification of $500 \mathrm{X}$.

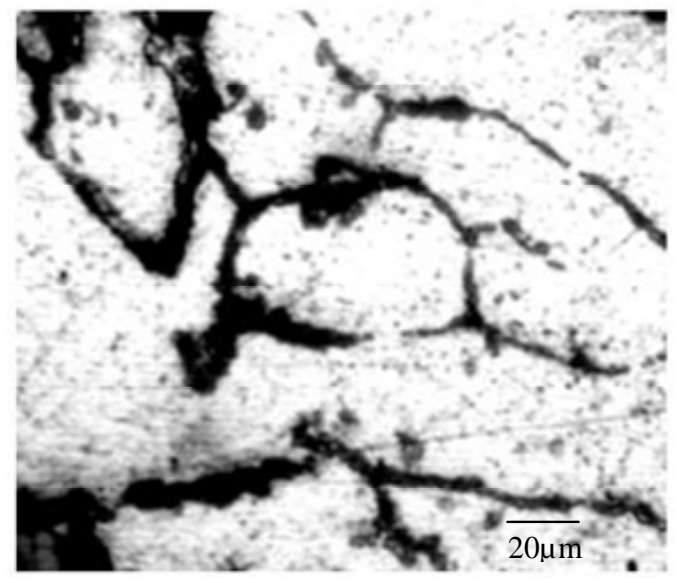

(a)

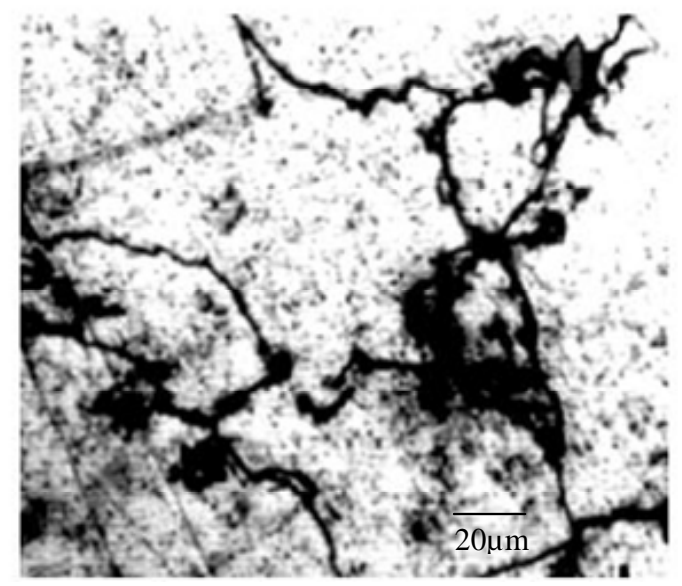

(b)

Figure 7. Optical microstructure of precipitation hardened 6061 aluminium compact with aluminium grain size of $150 \mu \mathrm{m}$ at a furnace cooled temperature of (a) $600^{\circ} \mathrm{C}$ and (b) $200^{\circ} \mathrm{C}$ after sintering, at a magnification of $500 \mathrm{X}$. 


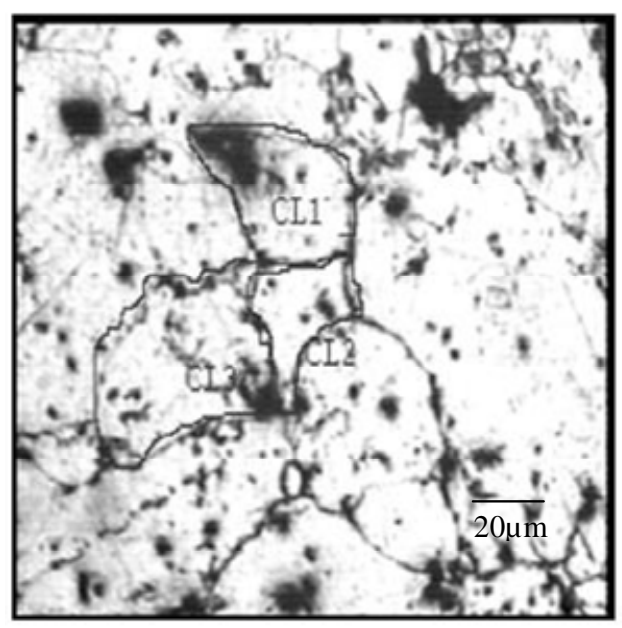

(a)

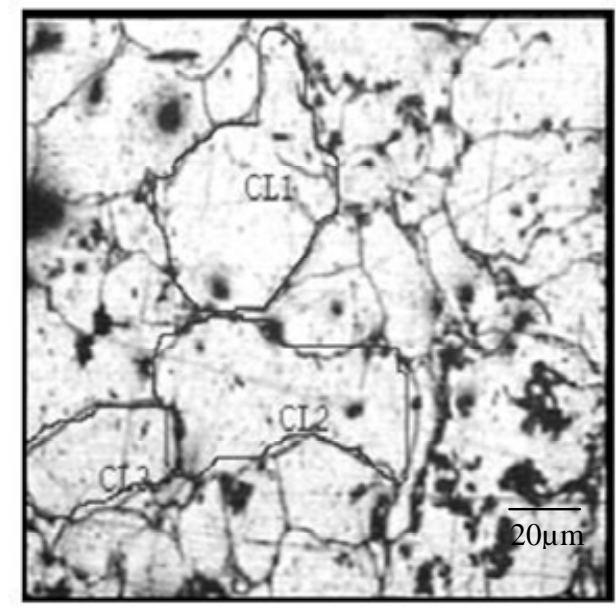

(b)

Figure 8. Grain Size measurement for precipitate hardened6061 aluminium compact with aluminium grain size of $150 \mu \mathrm{m}$, a furnace cooled temperature of (a) $600^{\circ} \mathrm{C}$ and (b) $200^{\circ} \mathrm{C}$ after sintering.

is shown in Figure 9. For a precipitate hardened 6061 aluminium compact furnace cooled after sintering at $200^{\circ} \mathrm{C}$ with aluminium particle size $20 \mu \mathrm{m}$ the porosity level is apparently equal to $6.14 \mathrm{vol} \%$ and that for an aluminium particle size of $150 \mu \mathrm{m}$ the porosity level is apparently equal to $7.82 \mathrm{vol} \%$. This variation in porosity level for the various aluminium particle size used may be related to compressibility [13], which is good for finer aluminium particle size of $20 \mu \mathrm{m}$ when compared with aluminium particle size of $150 \mu \mathrm{m}$. Similar results of reduced porosity level during slow cooling have been reported, in the work by Kent et al., [14], on age hardening of sintered Al-Cu-Mg-Si-Sn alloy systems. Precipitation induced densification due to furnace controlled cooling after sintering observed here, is also similar to that of the work reported by Lumley et al., [9], on precipitation induced densification due to increase in copper content in a sintered Al-Zn-Mg-Cu alloy.

\subsection{Density}

The density of the sintered, solution heat treated and artificial hardened specimens are measured according to ASTM B238 standards. The various density values measured are shown in Figure 10.

The increase in density for precipitate hardened compacts is mainly due to the precipitation of various phases formed during sintering, into the aluminium matrix during solution heat treatment and artificial hardening process, which further leads to increased aluminium grain size as discussed earlier. The result obtained is similar to that of the precipitation induced densification due to increase in copper content in a sintered $\mathrm{Al}-\mathrm{Zn}-\mathrm{Mg}-\mathrm{Cu}$ alloy, reported by Lumely et al., [9]. Maximum density value obtained for precipitation hardened aluminium compacts are $2.62 \mathrm{~g} \cdot \mathrm{cm}^{-3}$ and $2.59 \mathrm{~g} \cdot \mathrm{cm}^{-3}$ for an aluminium particle size of $20 \mu \mathrm{m}$ and $150 \mu \mathrm{m}$ respectively. The observed density values are lower as that reported by Showaiter $e t$ $a l$, [15] on their work on "Compaction, sintering and mechanical properties of elemental $6061 \mathrm{Al}$ powder with and without sintering aids" may be due to the decrease in compaction pressure.

\subsection{Micro Hardness}

Variations in micro hardness for various furnace cooled temperature after sintering for 6061 aluminium compacts with aluminium particle size of $20 \mu \mathrm{m}$ and $150 \mu \mathrm{m}$ are shown in Figure 11. Irrespective of particle size, the densification of aluminium grains taken place during furnace controlled cooling up to $200^{\circ} \mathrm{C}$, has proved enhanced hardness. The ability to measure micro hardness increases within the grain improved, without interception of the pores which retards hardness measurement. It is presumed that the dissolution of alloy powders taken place in aluminium solid solution. The slow cooling enhances the grain growth, which could be seen and measured through the microscope. The measurement of micro hardness clearly showed the enhanced hardness at $200^{\circ} \mathrm{C}$. It is evident that increase in density as the cooling is effected from $200^{\circ} \mathrm{C}$ after sintering, increases the hardness for a given matrix. Irrespective of aluminium particle size, the hardness value increases for 6061 aluminium compacts sintered, solution heat treated and precipitate hardened, as the furnace cooled temperature after sintering decreases to $200^{\circ} \mathrm{C}$. For precipitate hardened 6061 aluminium compact furnace cooled at $200^{\circ} \mathrm{C}$, the micro hardness reaches a value of $\sim 57 \mathrm{HV}_{0.5}$ for aluminium particle size of $20 \mu \mathrm{m}$ and $\sim 46 \mathrm{HV}_{0.5}$ for aluminium particle size of $150 \mu \mathrm{m}$. The increase in hardness value on 


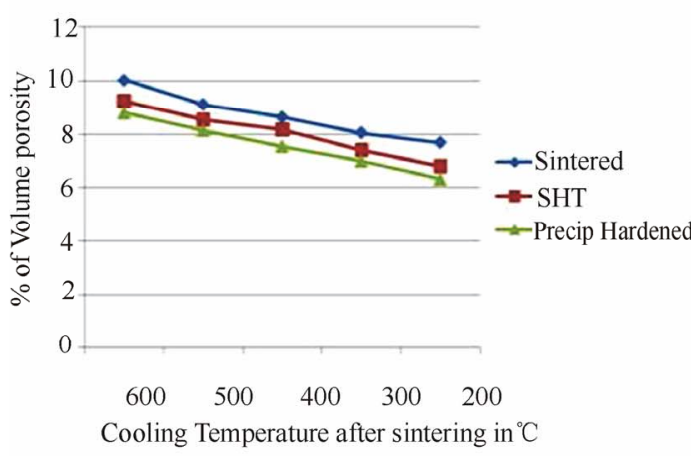

(a)

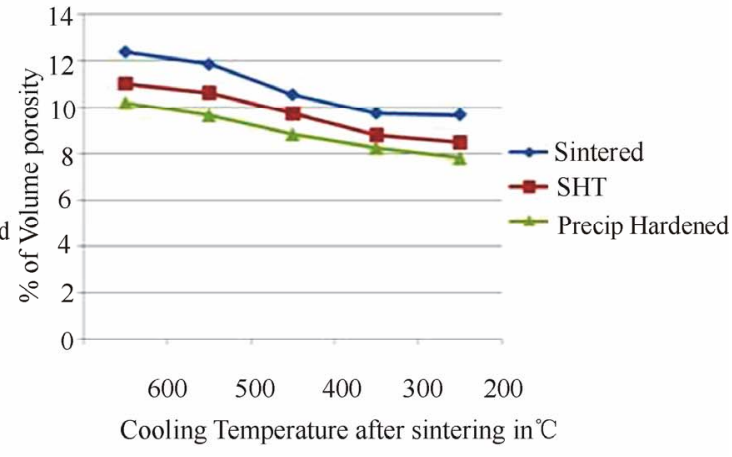

(b)

Figure 9. Porosity level of a aintered, solution heat treated and precipitate hardened 6061 aluminium compacts for various fumace controlled temperatures after sintering for an aluminium partocle size of (a) $20 \mu \mathrm{m}$ (b) $150 \mathrm{\mu m}$.

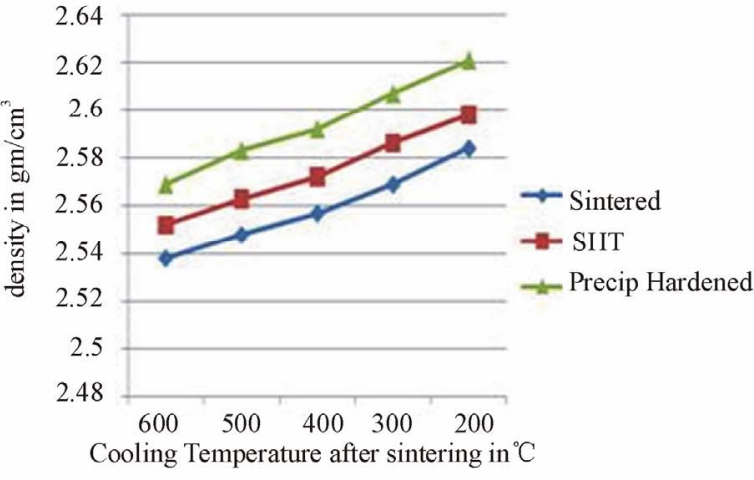

(a)

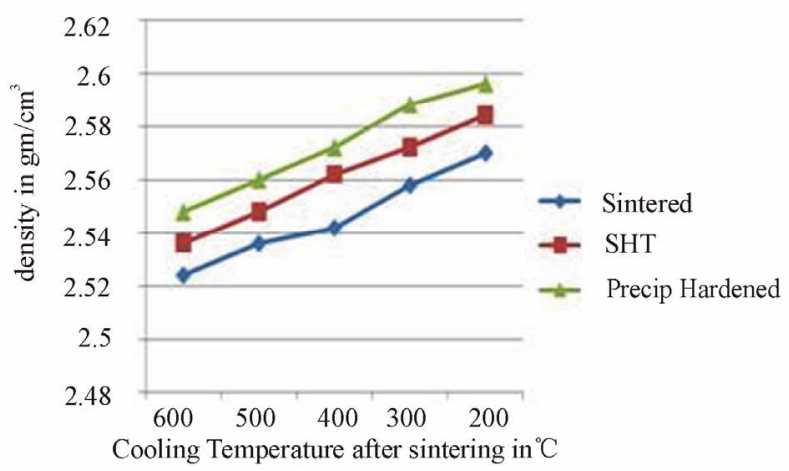

(b)

Figure 10. Various density of 6061 aluminium compacts, fumace cooled after sintering at various cooling temperature, with aluminium particle size of (a) $20 \mathrm{\mu m}$ (b) $150 \mu \mathrm{m}$.

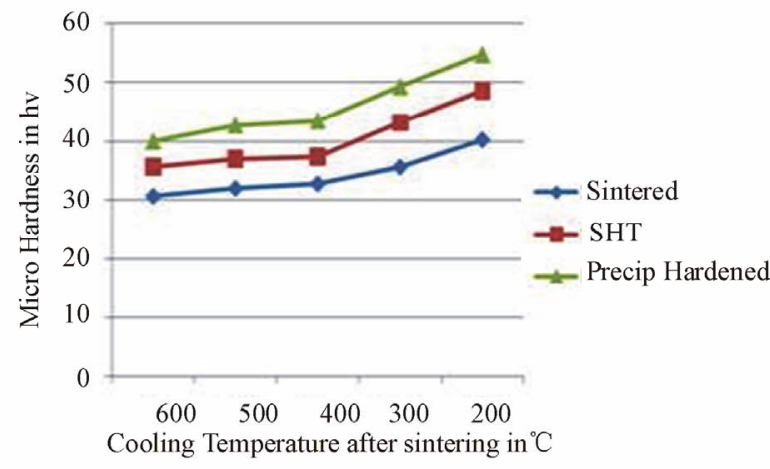

(a)

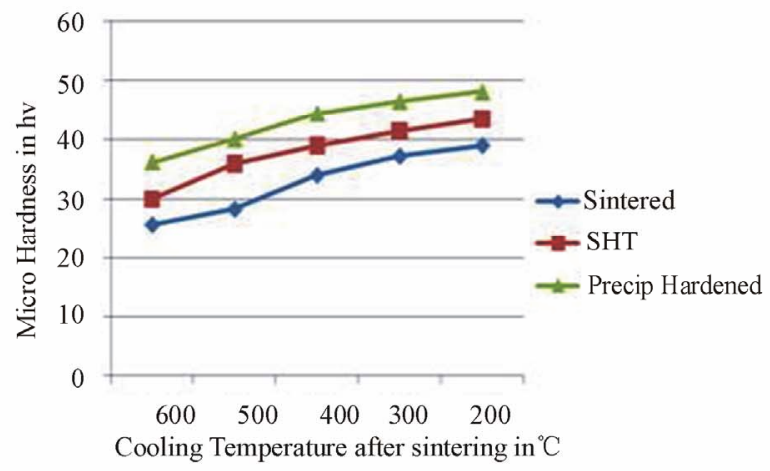

(b)

Figure 11. Various micro hardness of 6061 aluminium compacts, fumace cooled after sintering at various cooling temperature, with aluminium particle size of (a) $20 \mu \mathrm{m}$ (b) $150 \mu \mathrm{m}$.

furnace controlled cooling after sintering is similar to the results reported by Kent et al., [14] in the age hardening of a sintered Al-Cu-Mg-Si-(Sn) alloy. The time taken to achieve peak hardness increased at low furnace cooled temperature of $200^{\circ} \mathrm{C}$ after sintering is due to fact that the rate of precipitation is largely controlled by diffusion of solute elements which is highly dependent on cooling temperature [16]. The prolonged furnace controlled cooling to reach peak hardness was also observed in near dense wrought $2014 \mathrm{Al}$ alloys [17,18]. 


\section{Conclusions}

The following points have been concluded from the work.

1) Furnace controlled cooling after sintering reduces porosity level due to densification of various phases formed irrespective of aluminium grain size.

2) Due to densification of the phases, grain size enlargement takes place which results in higher density values.

3) Pores are mainly formed at the aluminium particle boundaries and at boundaries of various undissolved phases formed by the alloying elements and these phases formed precipitates during solution heat treatment due to which grain size enlargement and pore size reduction takes place.

Irrespective of aluminium particle sizes, the porosity level may be much more reduced if the compaction pressure is further raised.

\section{REFERENCES}

[1] I. J. Polmear, "Light Alloys-Metallurgy of the Light Metals," Third edition, Arnold, London, 1995.

[2] D. Slavnich, "Electric and Hybrid Vehicle," Journal of Automobile Engineering, Vol. 27, 2002, pp. 52-60.

[3] G. B. Schaffer, Material Forum 24, 2000, pp. 109-125.

[4] A. Salak, "Ferrous Powder Metallurgy," Cambridge International Science Publishing, Cambridge, 1997.

[5] N. Chawala, B. Jester and D. T. Vonk, "Bauschinger Effect in Porous Sintered Steels," Journal of Materials Science Engineering A, Vol. 346, No. 1-2, 2003, pp. 266272. doi:10.1016/S0921-5093(02)00542-7

[6] N. Chawala, D. Babic, J. J. Williams, S. J. Polasik, M. Marcucci and K. S. Narasimhan, "Advances in Powder Metallurgy and Particulate Materials,” MPIF, 2002, p. 104.

[7] N. Chawala, T. F. Murphy, K. S. Narasimhan, M. Koopman and K. K. Chawala, "Axial Fatigue Behavior of Binder-Treated Versus Diffusion Alloyed Powder Metallurgy Steels,” Material Science Engineering A, Vol. 308, No. 1-2, 2001, pp. 180-188. doi:10.1016/S0921-5093(00)01990-0

[8] S. Polasik, J. J. Williams and N. Chawala, "Fatigue Crack Initiation and Propagation of Binder-Treated Powder
Metallurgy Steels,” Metallurgical Material Transaction A, Vol. 33A, 2002, pp. 73-81. doi:10.1007/s11661-002-0006-8

[9] R. N. Lumely and G. B. Schaffer, "Precipitation Induced Densification in a Sintered Al-Zn-Mg-Cu alloy,” Journal of Scripta Materials, Vol. 55, No. 3, 2006, pp. 207-210. doi:10.1016/j.scriptamat.2006.04.021

[10] R. N. Lumley and G. B. Schaffer, "Surface Oxide and the Role of Magnesium in Liquid Phase Sintering," Journal of Scripta Materials, Vol. 35, No. 5, 1996, pp. 589-595. doi:10.1016/1359-6462(96)00195-9

[11] R. N. Lumley and G. B. Schaffer, "The Effect of Additive Particle Size on Sintered Al-Cu Alloys,” Journal of Scripta Materials, Vol. 39, No. 8, 1998, pp. 1089-1094. doi:10.1016/S1359-6462(98)00278-4

[12] ASM Handbook Metallography and Microstructures, Vol. 9, 2004.

[13] M. Rahimian, N. Ehsania, N. Parvin and H. Baharvandi, "The Effect of Particle Size, Sintering Temperature and Sintering Time on the Properties of $\mathrm{Al}-\mathrm{Al}_{2} \mathrm{O}_{3}$ Composites, Made by Powder Metallurgy," Journal of Material Processing Technology, Vol. 209, No. 14, 2009, pp. 53875393. doi:10.1016/j.jmatprotec.2009.04.007

[14] D. Kent, G. B. Schaffer and J. Drennan, "Age Hardening of a Sintered Al-Cu-Mg-Si-(Sn) Alloy,” Journal of Materials Science Engineering A, Vol. 405, No. 1-2, 2005, pp. 65-73. doi:10.1016/j.msea.2005.05.104

[15] N. Showaiter and M. Youseffi, “Compaction, Sintering and Mechanical Properties of Elemental 6061 Al Powder with and without Sintering Aids," Journal of Materials and Design Vol. 29, No. 4, 2008, pp. 752-762. doi:10.1016/j.matdes.2007.01.027

[16] J. W. Martin, "Precipitation Hardening,” Second Editon, Oxford, 1998.

[17] W. Bonfield and P. K. Datta, "Precipitation Hardening in Al-Cu-Si-Mg Alloy at $130-220^{\circ}$ C,” Journal of Material Science, Vol. 11, 1976, pp. 1661-1666. doi:10.1007/BF00737522

[18] L. Dutta, C. P. Harper and G. Dutta, "The Control of Grain Size and Distribution of Particles in a (6061 Al$\operatorname{loy}_{\mathrm{m}} /\left(\mathrm{Al}_{2} \mathrm{O}_{3}\right)_{\mathrm{P}}$ Composite by Solutionizing Treatment," Journal of Metallurgical and Materials Transactions A, Vol. 25, 1994, pp. 1591-1602. doi:10.1007/BF02668525 